\title{
Schedule II Substance
}

National Cancer Institute

\section{Source}

National Cancer Institute. Schedule II Substance. NCI Thesaurus. Code C48675.

A categ ory of drugs considered to have a strong potential for abuse or addiction but that also have legitimate medical use. 